\title{
ANALISIS HUKUM TERHADAP PELAKSANAAN OUTSOURCING DARI SISI PERUSAHAAN PENGGUNA JASA PEKERJA
}

\author{
Kadek Agus Sudiarawan \\ Fakultas Hukum Universitas Udayana, Bali
}

\begin{abstract}
Abstrak
Tujuan penelitian ini adalah untuk mengetahui dasar pertimbangan suatu perusahaan dalam menggunakan jasa pekerjaoutsourcing pada perusahaan tersebut dan untuk mengetahui bagaimanakah perusahaan pengguna jasa pekerjaoutsourcing dalam menjamin hak-hak perkerjaoutsourcing. Penelitian dilaksanakan dengan menggunakan metode normatif empiris.Data yang digunakan dalam penelitian ini terdiri dari data primer dan data sekunder.Seluruh data yang terkumpul dianalisis dengan menggunakan metode kualitatif.Hasil penelitian ini disajikan dalam suatu laporan yang bersifat diskriptif analisis. Hasil penelitian menunjukkan dasar pertimbangan perusahaan dalam menggunakan tenaga outsourcing ialah dapat dilihat dari sisi efektifitas, dimana perusahaan pengguna jasa tidak perlu lagi memikirkan tanggung jawab dalam urusan atau pekerjaan yang bukan merupakan kegiatan inti, karena sebagian urusan yang merupakan kegiatan penunjang telah diserahkan kepada perusahaan penyedia jasa. Oleh karena itu, terdapat pembagian resiko antara perusahaan pengguna jasa dengan perusahaan penyedia jasa. Sementara terkait perlindungan terhadap hak-hak pekerja outsourcing ditemukan fakta bahwa beberapa perusahaan outsourcing tidak memberikan perlindungan terhadap hakhak tenaga outsourcing dengan baik sehingga perusahaan pengguna jasa harus ikut berperan dalam memberikan perlindungan terhadap pekerja outsourcing sesuai dengan yang diatur dalam peraturan perundang-undangan yang berlaku.
\end{abstract}

Kata Kunci : Pelaksanaan, Outsourcing, Perusahaan Pengguna

\begin{abstract}
The purpose of this research is to determine the basic consideration of a company in using the services of the outsorced workers in the company and to determine how that company (as a user of the outsorced workers) in ensuring the rights of the outsourced workers. This is a normative-empirical research. The data used in this research consisted of primary data and secondary data. All data were analayzed by using qualitatives methods. The results of this research are presented in a report that is descriptive analysis. The results of this research shows that the basic consideration of a company in using the outsourced workers is - from the efectiveness perspective - a company who uses them is no longer need to think about the responsibilities arise from the works that are not part of the core activities due to half of the works in the form of supporting activities have been transfered to the outsourcing company. Therefore, there is risk sharing between a company as the outsourced workers users and the outsourcing companies. On the other side, the fact related to the protection of the outsourced workers' rights shows that several outsourcing companies do not provide proper protection of the outsourced workers' rights causing the companies that use such outsourced workers to also play a role in giving such protection in accordance to the applicable laws and regulations.
\end{abstract}

Keywords: Implementation, Outsourcing, User Company

\section{PENDAHULUAN \\ Latar Belakang}

Dalam Hukum Ketenagakerjaan dapat ditemukan beberapa istilah seperti buruh, pekerja, karyawan, pegawai, majikan atau pengusaha. Istilah buruh sejak dulu sudah populer dan kini masih sering dipakai sebagaisebutan untuk kelompok tenaga kerja yang sedang memperjuangkan program organisasinya. Istilah pekerja dalam praktek sering dipakai untuk menunjukkan status hubungan kerja, seperti pekerja kontrak, pekerja borongan, pekerja harian, 
pekerja honorer, pekerja tetap, dan sebagainya. Sedangkan istilah karyawan atau pegawai lebih sering dipakai untuk data administrasi. ${ }^{1}$

Pendapat lain menyatakan bahwa istilah buruh sejak dulu diidentikkan dengan pekerja kasar, pendidikan dan penghasilan yang rendah pula. ${ }^{2}$ Bahkan, pada zaman kolonial terdapat istilah kuli, mandor atau semacamnya, yang menempatkan pekerja pada posisi yang lemah di bawah pengusaha, padahal keberadaan pekerja sangatlah penting artinya bagi kelangsungan perusahaan. Batasan pengertian Hukum Ketenagakerjaan, yang dulu disebut Hukum Perpekerjaan atau arbeidrechts juga sama dengan pengertian hukum itu sendiri, yakni masih beragam sesuai dengan sudut pandang masing-masing ahli hukum. Tidak satupun batasan pengertian itu dapat memuaskan karena masing-masing ahli hukum memiliki alasan tersendiri.Hampir seluruhnya melihat hukum ketenagakerjaan dari berbagai sudut pandang yang berbeda, akibatnya pengertian yang dibuatnya tentu berbeda.

Secara khusus pengertianterkait apa yang disebut dengan pekerja dapat diklasifikasikan apabila memenuhi karakteritik sebagai berikut: ${ }^{3}$

1. Bekerja pada atau untuk pengusaha/perusahaan.

2. Imbalan kerjanya dibayar oleh pengusaha/perusahaan.

3. Secara resmi terang-terangan dan terus menerus mengadakan hubungan kerja dengan

pengusaha/perusahaan, baik untuk waktu tertentu maupun untuk jangka waktu tidak tertentu lamanya.

Sebelum membahas lebih jauh terkait hubungan kerja dalam Hukum

\footnotetext{
1 Abdul Hakim, 2003. Hukum Ketenagakerjaan Indonesia, Bandung: Citra Aditya Bakti, hlm.1.

${ }^{2}$ Budiono, Abdul Rachmat, 1995, Hukum Perburuhan di Indonesia, Cet. I, Jakarta: PT. RajaGrafindoPersada, hlm.1.

${ }^{3}$ Halim, A. Ridwan, 1990, Hukum Perburuhan dalam Tanya Jawab, Cet. II, Jakarta: Ghalialndonesia, hlm.11.
}

Ketenagakerjaan, ada baiknya kola terlebih dahulu dibahas apa yang dimaksud dengan para pihak dan pengertian-pengertian yang berkaitan dengan hubungan kerja, sesuai dengan yang dimaksudkan dalam ketentuan Umum Pasal 1 Undang-Undang Nomor 13 Tahun 2003 tentang Ketenagakerjaan (UU Ketenagakerjaan).

Pengertian dan pihak-pihak yang dimaksud adalah:

1. Ketenagakerjaan adalah segala hal yang berhubungan dengan tenaga kerja pada waktu sebelum, selama, dan sesudah masa kerja.

2. Tenaga kerja adalah setiap orang yang mampu melakukan pekerjaan guna menghasilkan barang dan atau jasa, baik untuk memenuhi kebutuhan sendiri maupun masyarakat.

3. Pekerja adalah setiap orang yang bekerja dengan menerima upah atau imbalan dalam bentuk lain.

4. Pemberi kerja adalah orang perseorangan, pengusaha, badan hukum, atau badan-badan lainnya yang memperkerjakan tenaga kerja dengan membayarkan upah atau imbalan dalam bentuk lain.

5. Pengusaha adalah:
a. Orang
perseorangan, persekutuan, atau badan hukum yang menjalankan suatu perusahaan milik sendiri.
b. Orang perseorangan, persekutuan, atau badan hukum yang secara berdiri sendiri menjalankan perusahaan bukan miliknya.
c. Orang perseorangan, persekutuan, atau badan hukum yang berada di Indonesia mewakili perusahaan sebagaimana yang dimaksud dalam poin 1 dan 2 yang berkedudukan di luar wilayah Indonesia.

6. Perusahaan adalah:

a. Setiap bentuk usaha yang berbadan hukum atau tidak, milik perseorangan, milik persekutuan, atau milik badan hukum, baik milik swasta 
maupun milik Negara yang mempekerjakan pekerja dengan membayar upah atau imbalan dalam bentuk lain.

b. Usaha-usaha sosial dan usaha-usaha lain yang mempunyai pengurus dan mempekerjakan orang lain dengan membayar upah atau imbalan dalam bentuk lain.

7. Perjanjian kerja adalah perjanjian antara pekerja dengan pengusaha atau pemberi kerja yang memuat syarat-syarat kerja, hak, dan kewajiban para pihak.

Selanjutnya mengenai hubungan kerja, UU Ketenagakerjaan mendefinisikan hubungan kerja sebagai hubungan antara pengusaha dan pekerja berdasarkan perjanjian kerja yang mempunyai unsur pekerjaan, upah, dan perintah.UU Ketenagakerjaan secara khusus mengatur mengenai beberapa jenis perjanjian kerja yakni meliputi : Perjanjian Kerja Waktu Tertentu (PKWT), Perjanjian Kerja Waktu Tidak Tertentu (PKWTT) dan termasuk pula outsourcing. Pengaturan PKWT dan Outsourcing dalam UU Ketenagakerjaan dapat disebut sebagai upaya untuk mewujudkan pasar kerja yang fleksibel di Indonesia.

Membahas secara khusus mengenai outsourcing, pada dasarnya secara dapat dimaknai sebagai salah satu bentuk hubungan kerja yang tidak ada hubungan organisatoris antara organisasi dengan pekerja karena secara resmi pekerja adalah tetap pekerja dari perusahaan outsourcing. Gaji pekerjatersebut dibayarkan oleh perusahaan outsourcing setelah pihaknya memperoleh pembayaran dari perusahaan pemakai tenaga kerja, tentu dengan melalui pemotongan oleh perusahaan outsourcing. Adapun perintah kerja walaupun sejatinya diberikan oleh perusahaan pemakai tenaga, akan tetapi resminya juga diberikan oleh perusahaan outsourcing, dan biasanya perintah itu diberikan dalam bentuk paket. Kebanyakan dari tenaga kerja outsourcing ini adalah professional dibidangnya, muda dalam usia, dan mempunyai semangat kerja yang baik. Kekurangannya adalah karena tidak mempunyai kesempatan dan tidak mempunyai hubungan khusus dengan para penentu kebijaksanaan perusahaan. ${ }^{4}$

Dalam perkembangan dunia usaha saat ini, mempekerjakan tenaga kerja dalam ikatan kerja outsourcing sedang menjadi trend atau model bagi perusahaan, baik itu perusahaan milik negara maupun perusahaan milik swasta.Banyak perusahaan outsourcing yakni perusahaan yang bergerak dibidang penyediaan tenaga kerja aktif menawarkan ke perusahaan-perusahaan pemberi kerja, sehingga perusahaan yang memerlukan tenaga kerja tidak perlu susah-susah mencari, menyeleksi dan melatih tenaga kerja yang dibutuhkan. Menyikapi perkembangan tersebut, maka timbul pertanyaan apakah yang menjadi dasar pertimbangan suatu perusahaan dalam menggunakan tenaga outsourcing, dan selanjutnya bagaimana suatu perusahaan pengguna jasa tenaga outsourcing dalam menjamin hak-hak pekerjaoutsourcing, tentunya Hukum Ketenagakerjaan perlu menjawab kebutuhan dan perkembangan tersebut. Dengan berdasarkan pemaparan di atas, maka tulisan iniakan mengkaji secara khusus mengenai analisis hukum terhadap pelaksanaanoutsourcing, dari sisi perusahaan pengguna jasa.

\section{Rumusan Masalah}

Berdasarkan uraian pada latar belakang di atas, adapun beberapa rumusan masalah yang akan dibahasa dalam tulisan ini adalah sebagai berikut:

1. Apakah yang menjadi dasar pertimbangan suatu perusahaan dalam menggunakan jasa tenaga outsourcing pada perusahaan tersebut?

2. Bagaimanakah perusahaan pengguna jasa tenaga outsourcing dalam menjamin hak-hak perkerjaoutsourcing?

\section{Tujuan Penulisan}

Adapun tujuan dari penulisan ini ialah meliputi :

\footnotetext{
${ }^{4}$ Suhardi, Gunarto, 2006, Perlindungan Hukum bagi Pekerja Kontrak Outsourcing, Yogyakarta: UAJY Press, hlm.2.
}

Jurnal IImu Sosial dan Humaniora | 837 
1. Untuk mengkaji dan mengetahui dasar pertimbangan suatu perusahaan dalam menggunakan jasa tenaga outsourcing pada perusahaan dan mengkaji bagaimana perusahaan pengguna jasa tenaga outsourcing dalam menjamin hak-hak pekerjaoutsoucing.

2. Untuk menambah wawasan dan pengetahuan bagi penulis di bidang ilmu hukum baik teori maupun praktek dalam hal ini lingkup Hukum Ketenagakerjaan khususnya terkait sistem outsourcing dalam dunia ketenagakerjaan Indonesia.

3. Untuk menerapkan ilmu dan teoriteori hukum yang telah penulis peroleh agar dapat memberi manfaat bagi penulis sendiri secara khusus, institusi dan masyarakat pada umumnya.

\section{METODELOGI PENELITIAN}

Penelitian hukum merupakan suatu kegiatan ilmiah, yang didasarkan pada metode, sistematika dan pemikiran tertentu yang bertujuan untuk mempelajari satu atau beberapa gejala hukum tertentu dengan jalan menganalisisnya secara lebih dalam. ${ }^{5}$

Jenis Penelitian yang digunakan dalam tulisan ini termasuk ke dalam penelitiannormatif empiris. Data yang digunakan dalam penelitian ini terdiri dari data primer dan data sekunder.Seluruh data yang terkumpul dianalisis dengan menggunakan metode kualitatif. Hasil penelitian ini disajikan dalam suatu laporan yang bersifat diskriptif analisis.

\section{PEMBAHASAN \\ Dasar Pertimbangan Penggunaan Tenaga Outsourcing Bagi Perusahaan}

Pada era globalisasi dimana perkembangan ekonomi global dan kemajuan teknologi begitu cepat seperti sekarang ini, penggunaan jasa penyedia tenaga kerja menjadi trend di tengah perkembangan persaingan bisnis yang

\footnotetext{
${ }^{5}$ Soerjono Soekanto, 1986, Pengantar Penelitian Hukum, UI Press, Jakarta, hal.43.
}

semakin kompetitif. Pengusaha berlombalomba untuk mendapatkan hasil dan keuntungan dengan maksimal dengan menekan pengeluaran yang minimal.Pengelolaan usaha memerlukan perubahan sistem, dengan memperkecil rentang kendali menagemen, dengan memangkas sedemikan rupa sehingga dapat menjadi lebih efektif, efisien dan produktif. Perusahaan lupa dari sejarah telah terbukti gaya potong memotong ongkos ini ada limitnya, baik itu batas ekonomi maupun batas etika. ${ }^{6}$ Perusahaan kemudian menerapkan sistem kerjaoutsourcing yaitu memborongkan satu bagian atau beberapa bagian kegiatan perusahaannya yang tadinya dikelola sendiri kepada perusahaan lain, yang kemudian disebut perusahaan penerima pekerjaan. ${ }^{7}$

Pelaksanaan outsourcing dalam beberapa tahun terakhir setelah terbitnya UU Ketenagakerjaan masih mengalami berbagai kelemahan terutama hal ini disebabkan kurangnya regulasi yang dikeluarkan pemerintah sebagai bentuk antisipasi terhadap ketidakadilan dalam pelaksanaan hubungan kerja antara pengusaha dan pekerja. ${ }^{8}$ Konsepsi hubungan hukum yang terjadi antara pekerja dengan pengusaha seringkali berada dalam hubungan sub-ordinat, atau hubungan dimana kedudukan pekerja lebih rendah dari pengusaha, dalam hal ini bagi pekerjaoutsourcing hal tersebut menjadi semakin parah, karena pekerja tidak mempunyai hubungan kerja dengan perusahaan pemberi kerja. Seharusnya hubungan industri antara pengusaha, pekerja dan pemerintah didasarkan atas nilai-nilai yang merupakan manifestasi dari keseluruhan nilai-nilai Pancasila dan Undang-Undang Dasar Negara Republik IndonesiaTahun 1945 yang tumbuh dan bekembang diatas kepribadian bangsa

\footnotetext{
${ }^{6}$ Gunarto Suhardi, 2006. Perlindungan Hukum Bagi Para Pekerja Kontrak Outsourcing,Yogjakarta: Universitas Atmaja, hlm.1.

${ }^{7}$ Muzni Tambusai, 2004. Pelaksanaan Outsourcing Ditinjau dari Aspek Hukum KetenagakerjaanTidak Mengaburkan Hubungan Industrial, dalam Informasi Hukum Vol.1 Tahun VI, hlm.209.

${ }^{8}$ Ani Wijayanti, 2003.Penyerahan Sebagian Pelaksanaan Pekerjaan kepada Perusahaan Lain dalam Undang-Undang No.13 Tahun 2003, dalam Bunga Rampai Masalah-Masalah Hukum Masa Kini, Jakarta: UKI Press, hlm.66.
}

Jurnal IImu Sosial dan Humaniora | 838 
dan kebudayaan nasional, sehingga hakekat keadilan sosial yang dicitacitakan dunia ketenagakerjaan dapat terwujud. ${ }^{9}$

Pelaksanaan outsourcing pada suatu perusahaan juga akan atau dapat membawa pengaruh tersendiri terhadap sistem organisasi dalam perusahaan tersebut. Dimana, dalam penerapan outsourcing juga memberikan keuntungan strategis, teknik dan tranformasional bagi organisasi, seperti memberikan pengaruh terhadap bentuk organisasi perusahaan, para pekerja dan kegiatan operasional perusahaan tersebut. Pengaruh outsourcing dalam bentuk organisasi perusahaan adalah mengubah suatu bentuk organisasi bisnis dari bentuk monolitik yang menjalin semua fungsi dan proses menjadi satu, menjadi suatu bentuk baru dimana organisasi bisnis inti yang merupakan kunci sukses perusahaan dipisahkan secara tersendiri.

Organisasi yang bekerja pada bisnis inti tersebut dalam perkembangan selanjutnya dikelilingi dan didukung oleh fungsi dan proses yang di alihdayakan kepada perusahaan penyedia jasa. Organisasi perusahaan yang bekerja pada kegiatan inti tidak akan terpecah pada urusan atau kegiatan penunjang, untuk mengerjakan kegiatan inti dengan semaksimal mungkin. ${ }^{10}$

Implikasi penerapan outsourcing bagi perusahaan dalam operasionalnya adalah dari sisi pengaturan, pemberian perintah, dan pengawasan kegiatan tidak perlu dilakukan oleh perusahaan pengguna jasa kepada tenaga kerjanya.Pengaturan pemberian perintah dan pengawasan kegiatan cukup dilakukan dengan menetapkan suatu fungsi pekerjaan atau urusan tertentu direalisasikan oleh perusahaan penyedia jasa outsourcing. Perusahaan penggunaan jasa tidak perlu lagi menetapkan teknis pelaksanaan kegiatan operasional kepada para pekerja karena

\footnotetext{
${ }^{9}$ Sendjum H.Manulang,1990. Pokok-Pokok Hukum Ketenagakerjaan Indonesia, Jakarta: Rineka Cipta, hlm.145.

10 Chandra Suwondo, 2003. Outsourcing Implementasi di Indonesia, Jakarta: PT. Elek Kompotindo Kelompok Gramedia, hlm.24-25.
}

fungsi tersebut telah diserahkan kepada perusahaan penyedia jasa. Penggunaan jasa outsourcing dilihat dari sudut pandang pengusaha, dapat mempermudah merekrut tenaga kerja sesuai dengan kebutuhan perusahaan, termasuk pula mudah ketika ingin memutuskan hubungan pekerjaan.

Penggunaan outsourcing saat ini semakin meluas ke berbagai lini kegiatan perusahaan.Outsourcing memberikan keuntungan signifikan bagi penggunanya. Dalam arti konsep outsourcing di praktekkan secara utuh dan konsisten dalam memberikan keuntungan bagi pengusaha, pengguna jasa, pekerja dan perusahaan penyedia jasa.

Bagi tenaga kerja, dengan adanya outsourcing maka tenaga kerja di perusahaan outsourcing mendapatkan keuntungan berupa pengembangan karir sesuai dengan spesialiasinya serta tenaga kerja memiliki kesempatan untuk memperoleh pengetahuan, keterampilan, dan keahlian yang professional dan berkualitas tinggi. Tenaga kerja perusahaan yang melakukan aktivitas di luar bisnis inti seringkali kurang mendapat perhatian dari atasan perusahaan tersebut, mengingat tidak terlalu berfokus pada aktivitas diluar bisnis inti tersebut.Perusahaan outsourcing dapat mengembangkan karir, pengetahuan, keahlian, keterampilan dan profesionalitas pelaksanaan tugas di luar bisnis inti suatu perusahaan. Dipihak perusahaan penyedia jasa, dengan banyaknya perusahaan melakukan outsourcing, perusahaan penyedia jasa tentu akan terus berkembang seiring dengan maraknya permintaan atas penyedia jasa.

Outsourcing merupakan suatu objek usaha yang menjanjikan untuk digarap. Perkembangan teknologi serta persaingan pasar yang terus berkembang dan semakin pesat, akan meningkatkan permintaan kebutuhan penyedia jasa. Sejalan dengan itu, bisnis outsourcingakan semakin marak dan menghasilkan keuntungan yang lebih menjanjikan bagi perusahaan penyedia jasa outsourcing. Sehingga menarik kemudian untuk menganalisis secara lebih dalam terkait alasan atau dasar pertimbangan suatu perusahaan dalam 
menggunakan tenaga outsourcing sebagai pilihan dalam upaya pengembangan kegiatan usahanya.

Kecenderungan

beberapa

perusahaan untuk memperkerjakan tenaga outsourcing pada saat ini, umumnya dilatarbelakangi oleh strategi perusahaan untuk melakukan efisiensi biaya produksi (cost of production). Perusahaan berusaha untuk menghemat pengeluaran dalam membiayai Sumber Daya Manusia (SDM) yang bekerja di perusahaan yang bersangkutan dengan menggunakan sistem outsourcing. ${ }^{11}$ Alasan perusahaan menggunakan jasa outsourcing adalah salah satu bentuk pilihan strategis managemen sebagai suatu cara untuk meminimalisir biaya dan memperoleh keuntungan dari keunggulankeunggulan strategis yang dapat dihasilkan melalui outsourcing. Tujuan bisnis perusahaan dengan adanya outsourcing bisa tercapai dengan cepat karena operasional di dalam perusahaan tersebut memang dikerjakan oleh pihakpihak yang berkompeten di bidangnya. Adapun secara umum alasan strategis utama suatu perusahaan melakukan outsourcing ialah meliputi:

1. Outsourcing dapat meningkatkan fokus perusahaan. outsourcing pada bagian operasional atau bagianbagian apapun dapat menghemat biaya, dengan implementasi operasional yang baik karena dilakukan oleh pihak ketiga yang bisnisnya terfokus pada satu bidang. Menggunakan outsourcing dikarenakan meningkatnya persaingan bisnis.

2. Outsourcing memungkinkan untuk suatu pembagian resiko, dimana apabila aktivitas perusahaan dikontrakkan kepada pihak ketiga maka resiko akan ditanggung bersama pula. Dengan menyerahkan sebagian pekerjaannya kepada pihak ketiga berdasarkan ketentuan UU Ketenagakerjaan berarti memberi peluang kepada para pengusaha

${ }^{11}$ Adrian Sutedi, 2009. Hukum

Ketenagakerjaan, Jakarta: Sinar Grafika, hlm.207. untuk melakukan efisiensi dan dapat terhindar dari resiko ekonomis seperti: perselisihan atau PHK, jaminan sosial dan kesejahteraan lainnya. ${ }^{12}$

3. Dapat mempercepat keuntungan yang diperoleh dari proses reengineering, sumber daya perusahaan dapat digunakan untuk kebutuhan-kebutuhan lain.

4. Jasa yang diberikan oleh outsourcer lebih berkualitas dibanding dikerjakan sendiri, karena secara internal outsourcer memang memiliki spesialisasi di bidang tersebut.

5. Memungkinkan tersedianya danadan dapat menciptkan dana segar.

6. Memperoleh sumber daya yang tidak dimiliki sendiri. Perusahaan dapat melakukan outsourcing untuk suatu aktifitas tertentu karena perusahaan tidak memiliki sumber daya yang dibutuhkan untuk melakukan aktifitas tersebut secara baik dan memadai.

7. Mengurangi resiko kegagalan dalam investasi.

8. Memecahkan masalah yang sulit dikendalikan dan dikelola. Outsourcing digunakan untuk mengatasi pengelolaan hal untuk mengawasi fungsi yang sulit dikendalikan, misalnya birokrasi ekstern yang sangat berbelit, yang sulit ditembus cara-cara biasa.

9. Kontrol yang lebih baik. Perusahaan dengan outsourcing bisa lebih baik mengontrol operasional perusahaannya. Hasilnya akan membuat bisnis menjadi lebih lantjar, efektif dan efisien.

Hal-hal strategis sebagaimana disebutkan diatas kemudian yang menjadi dasar pertimbangan utama mengapa perusahaan kemudian memilih menggunakan tenaga outsourcing untuk membantu proses pengembangan perusahaannya pada iklim persaingan

12 Syauffi Syamsuddin, 2005. Peluang dan Tantangan Penyerahan SebagianPekerjaan Kepada Pihak Ketiga, dalam Informasi HukumVol.3, Tahun VII, hlm.11. 
bisnis kompetitif seperti sekarang ini. Berdasarkan hal tersebut, konsepsi outsourcing dalam perspektif bisnis merupakan hal yang positif.Outsourcing memberikan pengaruh dan keuntungan yang signifikan bagi perusahaan pengguna jasa, perusahaan penyedia jasa dan tenaga kerja.

Outsourcing secara makro ekonomi dilakukan dengan memberikan keuntungan nasional seperti melindungi devisa negara, kesempatan memperoleh outsourcing atas produk negara lain dan berkembangnya sektor industri jasa skala kecil. Selain itu penerapan outsourcing juga dapat mengembangkan kemitraan usaha, sehingga suatu perusahaan tidak akan menguasai suatu keinginan industri dari hulu ke hilir, sehingga pemusatan kegiatan industri diperkotaan menjadi lebih merata ke daerah-daerah.

Outsourcing juga dapat memberikan manfaat untuk mengembangkan dan mendorong pertumbuhan ekonomi masyarakat dan pertumbuhan ekonomi nasional melalui pengembangan kegiatan usaha kecil, menengah dan koperasi. Masyarakat dan tenaga kerja mendapatkan manfaat dari pelaksanaan program outsourcing melalui aktivitas industri didaerah, yang akan mendorong kegiatan ekonomi penunjang di lingkungan masyarakat dan berkembangnya infrastruktur sosial, budaya kerja, disiplin dan peningkatan kemampuan ekonomi. Adanya industri di daerah akan mengurangi pengangguran sehingga urbanisasi dapat dicegah. ${ }^{13}$

\section{Perlindungan Perusahaan Pemberi Kerja Terhadap Hak-Hak PekerjaOutsourcing}

Perjanjian antara pekerja outsourcing dan perusahaan outsourcing berbentuk perjanjian tertulis.Perjanjian kerja outsourcing adalah seperti perjanjian pada umumnya karena memuat hak dan kewajiban para pihak.Pekerja dalam suatu perusahaan mempunyai kedudukan secara ekonomi dan sosial lebih rendah

13 Sehat Damanik, 2007, Outsourcing dan Perjanjian Kerja Menurut Undang-undang No. 13 Tahun 2003 tentang Ketenagakerjaan, Cetakan kedua, Jakarta: DSS Publishing, hlm.47. daripada pengusaha, sehingga suatu perusahaan sering melanggar hak-hak pekerja termasuk tenaga outsourcing.

Hak-hak tenaga outsourcing adalah sama dengan tenaga kerja pada umumnya. Hak yang harus diperoleh oleh tenaga outsourcing harus sesuai dengan peraturan-peraturan yang berlaku seperti UU Ketenagakerjaan, UU Keselamatan dan Kesehatan Kerja, UU Jaminan Sosial Tenaga Kerja, UU Serikat Pekerja/Serikat Pekerja dan keputusan-keputusan menteri tenaga kerja.

Perusahaan-perusahan outsourcing di Indonesia sering mengabaikan peraturan perundang-undangan yang belaku sehingga sering terjadi pelanggaran hak-hak pekerjaoutsourcing.Pelanggaran terhadap hak-hak tenaga outsourcing ini harus dilindungi oleh pemerintah.

Masalah-masalah yang sering timbul terkait hak-hak pekerja pada pelaksanaan sistem outsourcing yakni meliputi :

1. Gaji dan Fasilitas

\section{a. Gaji}

Upah yang diberikan oleh Perusahaan pemberi kerja seringkali lebih rendah dari Upah Minimum Kabupaten(UMK) yang ditentukan oleh pemerintah setempat.

\section{b. Jaminan Perawatan Kesehatan}

Ketentuan perjanjian kerja antara perusahaan outsourcing dan harusnya sudah memberikan jaminan perawatan kesehatan bagi pekerja yang diatur juga di dalam UU Ketenagakerjaan.Jaminan yang diberikan oleh pengusaha kepada pekerja ini termasuk perlindungan yang wajib dilakukan. Selain itu, keselamatan dan kesehatan kerja harus diterapkan dan dilaksanakan di setiap tempat kerja. ${ }^{14}$ Namun dalam beberapa kondisi masih banyak ditemukan perusahaan outsourcing yang belum memberikan jaminan perawatan kesehatan bagi pekerja mereka. Seharusnya dilaksanakan bahwa ketentuan minimal yang berlaku pada Jamsostek. Jamsotek

14 Abdul Hakim, 2003. Hukum Ketenagakerjaan Indonesia, Bandung: Citra Aditya Bakti, hlm.65. 
(Jaminan Sosial dan Teknologi) adalah salah satu jaminan yang diberikan oleh pemerintah terhadap tenaga kerja. Tingkat iuran, jenis dan besarnya jaminan serta hak dan kewajiban lain dari para peserta diatur secara tegas dalam Undang-Undang, Peraturan Pemerintah, Keputusan Presiden dan Keputusan Menteri. ${ }^{15}$

\section{Pemutusan Hubungan Kerja}

Perusahaan outsourcing dapat melakukan pemutusan hubungan kerja terhadappekerja outsourcing tanpa pesangon atau kompensasi dalam bentuk apapun termasuk biaya pemulangan ke tempat asal rekrut apabila pihak kedua tanpa alasan yang sah tidak masuk kerja selama 5 (lima) hari kerja dianggap mengundurkan diri dan memutuskan perjanjian kerja secara sepihak. Dalam hal ini pihak kedua tidak berhak menuntut Pesangon maupun kompensasi apapun dari pihak pertama.

Analisis:

Ketentuan ini tidak sesuai dengan UU Ketenagakerjaan karena walaupun Pekerja tidak berhak mendapat pesangon, namun Pekerja berhak menerima uang pengganti hak sesuai Pasal 156 ayat (4) meliputi:

a. Cuti tahunan yang belum diambil dan belum gugur;

b. Biaya atau ongkos pulang untuk pekerja dan keluarganya ketempat dimana pekerja diterima bekerja;

c. Pengganti perumahan serta pengobatan dan perawatan ditetapkan 15\% (lima belas perseratus) dari uang pesangon dan/atau uang penghargaan masa kerja bagi yang memenuhi syarat;

d. Hal-hal lain yang ditetapkan dalam perjanjian kerja, peraturan perusahaan atau perjanjian kerja bersama.

Selain itu Pekerja juga berhak menerima uang pisah yang besarnya dan pelaksanaannya diatur dalam perjanjian kerja, peraturan perusahaan, atau perjanjian kerja bersama.Namun perusahaan outsourcing hanya dapat melakukan pemutusan hubungan kerja apabila telah melakukan pemanggilan sebanyak 2 (dua) kali secara patut dan tertulis.

Apabila pihak pertama melakukan pemutusan hubungan kerja ini sebelum berakhirnya perjanjian kerja di luar ketentuan yang tercantum dalam pasal 5 butir 3, 4, dan 5 maka Pihak pertama diwajibkan membayar kepada pihak kedua sebesar gaji pihak pertama sampai waktu seharusnya berakhir kontrak kerja ini.

Ketentuan perjanjian kerja ini tidak sesuai dengan UU Ketenagakerjaan karena selain uang yang jumlahnya sebesar gaji, pekerja berhak atas komponen upah yang digunakan sebagai dasar perhitungan uang pesangon, uang penghargaan masa kerja, dan uang pengganti hak yang seharusnya diterima yang tertunda, terdiri atas:

a. Upah pokok;

b. Segala macam bentuk tunjangan yang bersifat tetap yang diberikan kepada pekerja dan keluarganya, termasuk harga pembelian dari cuti yang diberikan kepada pekerja secara cuma-cuma, yang apabila cuti harus dibayar pekerja dengan subsidi, maka sebagai upah dianggap selisih antara harga pembeli dengan harga yang harus dibayar oleh pekerja .

Uang pesangon adalah uang dari pengusaha sebagai tambahan atas upah atau gaji yang menjadi hak pekerja semata-mata karena ia diperhentikan setelah bekerja pada pengusaha selama kurun waktu tertentu. ${ }^{16} \mathrm{Hal}$ ini sesuai dengan

16 Iman Soepomo, 1968. Pengantar

Hukum Perburuhan. Jakarta: Penerbit Djambatan, hlm.86. 
Pasal 157 ayat 1 UU Ketenagakerjaan.

Apabila pihak kedua melakukan pelanggaran berat sesuai dengan apa yang tercantum di bawah ini, maka Pihak pertama berhak melakukan pemutusan hubungan kerja tanpa diwajibkan memberikan ganti rugi kompensasi ganti rugi dalam bentuk apapun juga termasuk biaya pemulangan ke tempat asal rekrut.

Analisis:

Perjanjian kerja ini tidak sesuai dengan UU Ketenagakerjaan karena menurut Pasal 158 ayat 3 UU Ketenagakerjaan disebutkan bahwa Pekerja yang diputus hubungan kerjanya berdasarkan alasan kesalahan/pelanggaran berat dapat memperoleh uang penggantian hak sebagaimana dimaksud dalam Pasal 156 ayat (4) yang meliputi:

a. Cuti tahunan yang belum diambil dan belum gugur;

b. Biaya atau ongkos pulang untuk pekerja dan keluarganya ketempat dimana pekerja diterima bekerja;

c. Pengganti perumahan serta pengobatan dan perawatan ditetapkan 15\% (lima belas perseratus) dari uang pesangon dan/atau uang penghargaan masa kerja bagi yang memenuhi syarat;

d. Hal-hal lain yang ditetapkan dalam perjanjian kerja, peraturan perusahaan atau perjanjian kerja bersama.

Dari hasil penelitian tersebut diketahui bahwa banyak perusahaan outsourcing kurang memperhatikan hakhak dari tenaga outsourcing. Berdasarkan pertimbangan hukum Mahkamah Konstitusi dalam putusannya Nomor 27/PUU-IX/2011 dan Penjelasan Pasal 66 ayat (2) huruf (c) UUK, pekerjayang bekerja pada perusahaan outsourcingsesuai dengan perjanjian kerja, peraturan perusahaan, atau perjanjian kerja bersama, memperoleh hak (yang sama) atas perlindungan upah dan kesejahteraan, syarat-syarat kerja, serta perselisihan yang timbul, dengan pekerja di perusahaan pemberi kerja (fair benefits and welfare).

Bagi pekerja perusahaan outsourcing yang bekerja di perusahaan klien harus memahami hak dan kewajibannya.Pemahaman ini penting untuk menghindari eksploitasi berlebihan yang dapat saja terjadi. ${ }^{17}$ Kesepakatan kerja yang terjadi harus melibatkan tenagaoutsourcing sebagai pekerja.Kesepakatan tidak boleh hanya terjadi antara perusahaan klien dengan perusahaan outsourcing. ${ }^{18}$

Berdasarkan hasil penelitian pula kemudian dapat diketahui bahwa banyak perusahaan outsourcing yang kurang memperhatikan hak-hak dari tenaga kerja outsourcing.Perusahaan outsourcing melakukan pelanggaran terhadap hak-hak tenaga outsourcing terlihat dari kontrak yang dibuat antara perusahaan outsourcing dan tenaga outsourcing.Kontrak-kontrak tersebut berisi ketentuan-ketentuan terkait hak-hak tenaga outsourcing yang tidak sesuai dengan peraturan yang berlaku.

Pekerjaoutsourcing pada dasarnya bekerja pada perusahaan klien meskipun tenaga outsourcing tersebut mendapatkan upah dari perusahaan outsourcing. Perusahaan klien sebagai perusahaan yang memberi kerja kepada tenaga outsourcing seharusnya memperhatikan hak-hak tenaga outsourcing meskipun kontrak kerja antara tenaga outsourcing dan perusahaan pemberi kerja adalah bersifat tidak langsung.

Perusahaan pemberi kerja harus memberikan penghargaan kepada tenaga outsourcing melalui pemberian hak-hak yang seharusnya didapat oleh pekerja atau tenaga kerja pada umumnya. Hakhak yang didapat itu adalah sebagaimana yang dimaksud oleh peraturan yang berlaku seperti UU Ketenagakerjaan yang mendasari peraturan terkait ketenagakerjaan.Pada kenyataannya ada beberapa perusahaan pemberi kerja tidak memperhatikan hak-hak dari tenaga outsourcing karena menganggap tidak

\footnotetext{
${ }^{17}$ Redaksi RAS, 2010. Hak dan Kewajiban Karyawan, Raih Asa Sukses, Jakarta, hlm.49.

${ }^{18}$ Agushamidah, Op.cit, hlm.36.
}

Jurnal IImu Sosial dan Humaniora | 843 
memiliki kontrak dengan tenaga outsourcing.Perusahaan pemberi kerja menganggap bahwa kontrak dibuat hanya antara perusahaan pemberi kerja dan perusahaan outsourcing.

Outsourcing harus mendasarkan pada ketentuan dan syarat-syarat sebagaimana yang diatur di dalam Pasal 64 dan Pasal 66 UU No. 13 Tahun 2003 tentang Ketenagakerjaan dan secara teknis diatur lebih lanjut dalam Keputusan Menteri Tenaga Kerja dan Transmigrasi No. KEP.101/MEN/VI/ 2004 Tahun 2004 tentang Tata Cara Perijinan Perusahaan Penyedia Jasa Pekerja .

Pasca uji materi (judicial review) terhadap Pasal 59 dan Pasal 64 UUKetenagakerjaan, dan kemudian melahirkan putusan Mahkamah Konstitusi Nomor 27/PUU-IX/2011, tertanggal 17 Januari 2012. Putusan Mahkamah Konstitusi ini kemudian memberikan efek kejut yang lebih dasyat bila dibandingkan Putusan Mahkamah Konstitusi Lainnya.Ada yang mengatakan dasar hukum outsourcing tidak sah pasca Putusan MK. Bahkan PKWT yang sudah ditandatangani sebelum Putusan Mahkamah Konstitusi oleh sebagian kalangan dinilai telah bertentangan dengan Putusan Mahkamah Konstitusi. ${ }^{19}$

maka selanjutnya terbitlah Surat Edaran Direktur Jenderal Pembinaan Hubungan Industrial dan Jaminan Sosial Tenaga Kerja Kementerian Tenaga Kerja dan Transmigrasi RI Nomor: B.31/PHIJSK/I/2012 tentang Pelaksanaan Putusan Mahkamah Konstitusi Nomor 27/PUU-IX/2011.

Surat Edaran tersebut yang dihubungkan dengan pertimbangan hukum dalam putusan Mahkamah Konstitusi Nomor 27/PUU-IX/2011, hubungan kerja antara Perusahaan Outsourcing dengan pekerja dapat dilakukan/diperjanjikan melalui Perjanjian Kerja Waktu Tidak Tertentu/Pekerjaan Tetap ("PKWTT") atau melalui Perjanjian Kerja Waktu Tertentu/Kontrak (“PKWT”).

${ }^{19}$ Artikel:http://www.hukumonline.com/berita/baca/lt4f4 b372fe9227/legalitas-ioutsourcing-i-pasca-putusan-mkbroleh--juanda-pangaribuan, diakses pada tanggal 5 Juni 2016.
Hubungan kerja yang diperjanjikan dengan PKWT maka pekerja harus tetap mendapat perlindungan atas hak-haknya sebagai pekerja dengan menerapkan prinsip pengalihan tindakan perlindungan bagi pekerja (Transfer of Undertaking Protection of Employment atau TUPE), apabila terjadi pergantian perusahaan pemberi kerja atau perusahaan outsourcing.

Prinsip pengalihan tindakan perlindungan (prinsipTransfer of Undertaking Protection of Employment atau TUPE), adalah jaminan kelangsungan hubungan kerja dan syaratsyarat kerja bagi pekerja dengan penghargaan masa kerja (experience) serta penerapan ketentuan kesejahteraan (upah) yang sesuai dengan pengalaman dan masa kerja yang dilalui seseorang pekerja.Prinsip pengalihan tindakan perlindungan (prinsip Transfer of Undertaking Protection of Employment atau TUPE), terdapat dalam butir 3.18 pertimbangan hukum Putusan Mahkamah Konstitusi Perkara Nomor 27/PUUIX/2011 yang menyatakan bahwa "dengan menerapkan prinsip pengalihan perlindungan, ketika perusahaan pemberi kerja tidak lagi memberikan pekerjaan borongan atau penyediaan jasa pekerja kepada suatu perusahaan outsourcingyang lama, dan memberikan pekerjaan tersebut kepada perusahaan outsourcingyang baru, maka selama pekerjaan yang diperintahkan untuk dikerjakan masih ada dan berlanjut, perusahaan penyedia jasa baru tersebut harus melanjutkan kontrak kerja yang telah ada sebelumnya, tanpa mengubah ketentuan yang ada dalam kontrak, tanpa persetujuan pihak-pihak yang berkepentingan, kecuali perubahan untuk meningkatkan keuntungan bagi pekerja karena bertambahnya pengalaman dan masa kerjanya".

Selanjutnya, disebutkan bahwa "...para pekerja outsourcing tidak diperlakukan sebagai pekerja baru. Masa kerja yang telah dilalui para pekerja outsourcingtersebut tetap dianggap ada dan diperhitungkan, sehingga pekerja outsourcing dapat menikmati hak-hak (:upah) sebagai pekerja secara layak dan 
proporsional" (vide Putusan MK Perkara Nomor 27/PUU-IX/2011, hal. 44 dan 45).

Mahkamah Konstitusi menyatakan dalam pertimbangan bahwa "untuk menghindari perusahaan (outsourcing company) melakukan eksploitasi pekerja hanya untuk kepentingan keuntungan bisnis tanpa memperhatikan jaminan dan perlindungan atas hak-hak pekerja untuk mendapatkan pekerjaan dan upah yang layak, dan untuk meminimalisasi hilangnya hak-hak konstitusional para pekerjaoutsourcing, Mahkamah Konstitusi menentukan dua model perlindungan dan jaminan hak bagi pekerja yang dapat dilaksanakan untuk melindungi hak-hak pekerja , yakni:

1. Pertama, dengan mensyaratkan agar perjanjian kerja antara pekerja dengan perusahaan yang melaksanakan pekerjaan outsourcing (outsourcing company) tidak berbentuk PKWT, melainkan berbentuk "perjanjian kerja waktu tidak tertentu (PKWTT)". Melalui model yang pertama tersebut, hubungan kerja dengan pekerja dengan perusahaan outsourcing, adalah konstitusional sepanjang dilakukan berdasarkan PKWTT.

2. Kedua, menerapkan prinsip pengalihan tindakan perlindungan bagi pekerja (TUPE) yang bekerja pada perusahaan outsourcing. Model yang kedua ini diterapkan, bahwa dalam hal hubungan kerja berdasarkan PKWT, maka pekerja harus tetap mendapat perlindungan dengan menerapkan prinsip TUPE (vide Putusan MK butir [3.18] hal.44).

Klausul "TUPE" (Transfer of Undertaking Protection Employment) atau prinsip pengalihan tindakan perlindungan bagi pekerja, mengamanatkan: ${ }^{20}$

1. Pengalihan perlindungan hak-hak bagi pekerja (termasuk berlanjutnya hubungan kerja dengan perusahaan outsourcing yang baru) yang objek

${ }^{20}$ Artikel

:http://www.hukumonline.com/klinik/detail/tt4f295d704fe05 /penerapan-prinsip-pengalihan-perlindungan-dalam-pkwtpasca-putusan-mk, diakses pada tanggal 10 Juni 2016. kerja-nya tetap ada walaupun terjadi pergantian perusahaan outsourcing.

2. Masa kerja pekerja harus diperjanjikan (dalam PKWT) untuk dibuat experience letter

3. Masa kerja menjadi salah satu dasar penentuan upah pada perusahaan outsourcing berikutnya.

Hubungan kerja pekerja pada suatu perusahaan outsourcing terkait kedua model tersebut pada prinsipnya haruslah PKWTT, namun jika memenuhi syarat sesuai ketentuan Pasal 59 No. 13 Tahun 2003, khususnya ayat (1) dan (2), maka dapat dilakukan (diperjanjikan) melalui PKWT. Pasal 59 ayat (1) UU No.13 Tahun 2003 berisi ketentuan bahwa bahwa PKWT hanya dapat diperjanjikan untuk pekerjaan tertentu yang menurut jenis dan sifat atau kegiatan pekerjaannya hanya (akan selesai) untuk waktu tertentu, yakni:

1. Pekerjaan yang sekali selesai (sementara sifatnya). Maksudnya, yang bersifat sporadik;

2. Pekerjaan yang (berdasarkan asumsi) perkiraan penyelesaiannya dapat dilakukan dalam waktu singkat dan tidak melebihi 3 (tiga) tahun. Artinya, jika asumsinya melebihi 3 (tiga) tahun, maka hubungan kerja pekerja harus dengan PKWTT.

3. Pekerjaan yang bersifat musiman (termasuk peak season); atau

4. Pekejaan yang merupakan produk baru, kegiatan baru, produk tambahan yang (semuanya) masih dalam masa percobaan atau penjajakan (launching).

\section{PENUTUP \\ Kesimpulan}

1. Dasar pertimbangan strategis perusahaan dalam menggunakan tenaga outsourcing ialah dalam kaitannya dengan efektifitas pelaksanaan outsoursing. Melalui hubungan kerja outsourcing aktivitas perusahaan pengguna jasa tidak perlu lagi memikirkan tanggung jawab dalam urusan atau pekerjaan yang bukan merupakan kegiatan inti (fokus pada bisnis inti), karena sebagian urusan yang merupakan kegiatan penunjang telah 
diserahkan kepada perusahaan penyedia jasa. Dengan demikan, terdapat pembagian resiko antara perusahaan pengguna jasa dengan perusahaan penyedia jasa dalam arti perusahaan pengguna jasa tidak lagi menanggung beban resiko sepenuhnya karena sebagian telah dialihkan atau diserahkan kepada perusahaan penyedia jasa.

2. Beberapa perusahaan outsourcing tidak memberikan perlindungan terhadap hak-hak tenaga outsourcing sehingga perusahaan pemberi kerja harus memberikan perlindungan yang lebih baik sesuai dengan yang diatur dalam peraturan perundang-undangan yang berlaku.

\section{Saran}

1. Perusahaan pengguna tenaga kerja outsourcing harus secara sungguhsungguh dan berhati-hati dalam menghitung resiko terutama hubungan kerja outsourcingkhususnya terkait keseimbangan tanggung jawab antara pengguna jasa dengan penyedia jasa agar tidak hanya menguntungkan bagi satu pihak (pengusaha atau pengguna jasa) namun juga berkeadilan dan mampu melindungi hak-hak pekerja dengan baik.

2. Untuk perusahaan pemberi kerja seharusnya lebih memperhatikan hak-hak tenga outsourcing sesuai dengan peraturan perundangundangan yang berlaku meskipun kontrak yang dibuat bukan antara perusahaan pemberi kerja dengan pekerjaoutsourcing melainkan dengan perusahaan outsourcing.

\section{DAFTAR PUSTAKA}

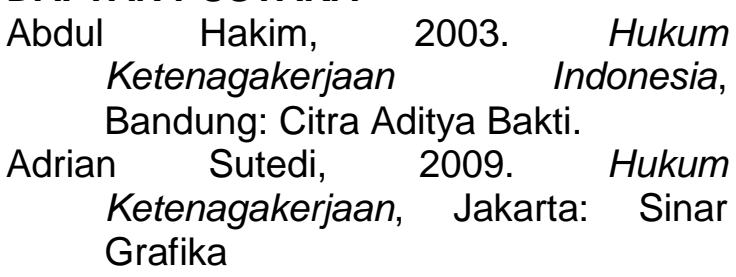

Agusmidah, 2010.Dinamika Hukum Ketenagakerjaan Indonesia, Medan: USU Press.
Ani Wijayanti, 2003.Penyerahan Sebagian Pelaksanaan Pekerjaan kepada Perusahaan Lain dalam UndangUndang No.13 Tahun 2003, dalam Bunga Rampai Masalah-Masalah Hukum Masa Kini, Jakarta: UKI Press.

Budiono, Abdul Rachmat, 1995, Hukum Perburuhan di Indonesia, Cet. I, Jakarta: PT. Raja Grafindo Persada.

Chandra Suwondo, 2003. Outsourcing Implementasi di Indonesia, Jakarta: PT. Elek Kompotindo Kelompok Gramedia.

Gunarto Suhardi, 2006. Perlindungan Hukum Bagi Para Pekerja Kontrak Outsourcing, Yogjakarta: Universitas Atmaja.

Halim, A. Ridwan, 1990, Hukum Perburuhan dalam Tanya Jawab, Cet. II, Jakarta: Ghalia Indonesia.

Iman Soepomo, 1968. Pengantar Hukum Perburuhan. Jakarta: Penerbit Djambatan.

Sehat Damanik, 2007, Outsourcing dan Perjanjian Kerja Menurut Undangundang No. 13 Tahun 2003 tentang Ketenagakerjaan, Cetakan kedua, Jakarta: DSS Publishing

Sendjum H.Manulang,1990. Pokok-Pokok Hukum Ketenagakerjaan Indonesia, Jakarta: Rineka Cipta.

Suhardi, Gunarto, 2006, Perlindungan Hukum bagi Pekerja Kontrak Outsourcing, Yogyakarta: UAJY Press.

Soerjono Soekanto, 1986, Pengantar Penelitian Hukum, UI Press, Jakarta.

Muzni Tambusai, 2004. Pelaksanaan Outsourcing Ditinjau dari Aspek Hukum Ketenagakerjaan Tidak Mengaburkan Hubungan Industrial, dalam Informasi Hukum Vol.1 Tahun $\mathrm{VI}$

Redaksi RAS, 2010. Hak dan Kewajiban Karyawan, Raih Asa Sukses, Jakarta.

Syauffi Syamsuddin, 2005. Peluang dan Tantangan Penyerahan Sebagian Pekerjaan Kepada Pihak Ketiga, dalam Informasi HukumVol.3, Tahun VII.

http://www.hukumonline.com/klinik/detail/lt 4f295d704fe05/penerapan-prinsip- 
pengalihan-perlindungan-dalam-

pkwt-pasca-putusan-mk

http://www.hukumonline.com/berita/baca/lt

4f4b372fe9227/legalitas-

ioutsourcing-i-pasca-putusan-mkbr-

oleh--juanda-pangaribuan

Undang-Undang No. 13 Tahun 2003 Tentang Ketenagakerjaan

Putusan Mahkamah Konstitusi Nomor. 27/PUU-IX/2011

Keputusan Menteri Tenaga Kerja dan Transmigrasi Nomor: KEP 100/ MEN/ VI/ 2004 Tentang Ketentuan Pelaksanaan Perjanjian Kerja Waktu Tertentu

Keputusan Menteri Tenaga Kerja Dan Transmigrasi Republik Indonesia No.Kep.101/Men/VI/2004 Tahun 2004 tentang Tata Cara Perijinan Perusahaan Penyedia Jasa Pekerja/Buruh

Surat Edaran Menteri Tenaga Kerja dan Transmigrasi Republik Indonesia Nomor: SE.04/MEN/VIII/2013 tentang Pedoman Pelaksanaan Peraturan Menteri Tenaga Kerja dan Transmigrasi Republik Indonesia Nomor 19 tahun 2012 tentang Syarat-syarat Penyerahan Sebagian Pelaksanaan Pekerjaan kepada Perusahaan lain

Surat Edaran Direktur Jenderal Pembinaan Hubungan Industrial dan Jaminan Sosial Tenaga Kerja Kementerian Tenaga Kerja dan Transmigrasi Republlk Indonesia Nomor: B.:n/PHIJSK/I/2012 tentang Pelaksanaan Putusan Mahkamah Konstitusi NOMOR 27/PUU-IXI2011 